of physiotherapists existed, and she was approached by each unit requesting that she consider working - to date 20 units. However, the Home Office restrictions prevent her from doing so. The sequelae to this negative approach are that the NHS will not benefit from the services of a skilled individual, bringing with her the experience of a famous unit abroad, and that her colleagues will be likely to be deterred from attempting to gain entry to Britain in the future, availing themselves instead of the more encouraging attitude offered by other countries.

J P DRIVER-JowitT

London WC1

\section{The Minister and the consultants}

SIR,-Many of your readers will have seen "Panorama" on BBC TV on 17 October. In it the Minister of Health informed the country that consultants were perfectionists. I was gratified to here this. It is the first piece of praise that the consultant body has received from that quarter for some time. However, he used this statement to imply that our repeated cries of deficiencies and of falling standards in the hospital service were therefore not to be taken seriously. He stated further that if there were any real deficiencies in the service we would no doubt inform him of these.

I suggest that the consultant body take up his valuable suggestion. It should not be difficult for each of us to find serious inadequacies in the hospital service, say, twice a week. Perhaps 22000 letters per week may shake him out of his cloud-cuckoo land.

It would be remiss of us to introduce political bias in our efforts to educate our political masters, so I suggest that copies of any letters should be sent to the Conservative shadow minister for his information.

\section{J A K Davies}

Pembroke County War Memorial

Hospital,
Haverfordwest, Dyfed

\section{Payment for on-call duties of clinical} assistants

SIR,-The medical staff committee at this hospital has directed me to write to you concerning reimbursement for on-call duties of clinical assistants.

One tends to wonder when the apparently fairly reasonable treatment meted out to general practitioners will ever be achieved by hospital consultants and it is difficult not to call to mind George Orwell and his "some pigs are more equal than others" when one sees that the Department of Health and Social Security approves of clinical assistants now being paid for "on-call" duties, with further reimbursement if they are actually called out. We, the hospital consultant staff, soldier on, coming in as necessary and sometimes frequently and merely recouping the cost of petrol.

I recall well about 10 years ago being one of many consultants holding evening clinical meetings and lecturing for no fee while those we lectured to were being paid to listen. It was a bit difficult to stomach at the time but eventually it was sorted out, and yet here we are again being far less "equal" and I wonder if it is generally known. Can we have it out in the open and try to achieve some sort of equality? In the meantime, and on a more personal note, I anticipate eagerly my travelling expenses of $74 \mathrm{p}$ being paid at the end of next month for the two hours that I spent in the hospital last Sunday afternoon dealing with an emergency.

A P C BACON Chairman, Scarborough District Medical Staff Committe

Scarborough Hospital,
Scarborough, N Yorks

${ }_{*}^{*}$ *The Secretary writes: "The new consultant contract, at present under negotiation with the Department of Health, as well as including one notional half day in the basic commitment for the consultant's continuing responsibility for patients currently under his care, makes provision for additional on-call responsibility to be recognised by the payment of fees varying with the degree of availability required. There is also provision for the payment of a fee on each occasion on which a consultant is recalled to hospital to deal with an emergency outside normal working hours."-ED, $B M F$.

\section{General practitioners' pay}

SIR,-It seems clear that there will be no pay rise before April 1978 and it is certain that any significant increase at that time will be achieved only by our negotiators demonstrating a realistic set of figures concerning increased productivity in terms of numbers of patients seen or numbers of prescriptions issued. Our negotiators were unable to convince the 1977 Review Body of any real increase in work load which would have enabled the Review Body to recommend significant pay rises within existing legislation. So that this error is not repeated it would be useful for the BMA, or whoever our negotiators may be, to request GPs to keep such figures and indicate how they should be obtained. Why is this not being done?

\section{J CRITChley}

Bexleyheath, Kent

${ }^{*}{ }_{*}$ The Secretary writes: "The problem of monitoring work load in general practice has been studied by the Association on several occasions in the past and it is quite clear that it is an extremely difficult task to obtain any meaningful figures. Nevertheless, in view of the requests by the Review Body for some firm data our economic research unit is now preparing an on-going study of work load. It is hoped that it will be possible for this to start in the very near future."- $\mathrm{ED}, B M \mathcal{F}$.

\section{Use of deputising services}

SIR,-The rejection by the Secretary of State of the appeal by Dr Maurice Buckley against the decision of the Walsall Family Practitioner Committee not to give him consent to use a deputising service is greatly to be deplored. If Dr Buckley is personally covering a substantial part of the 66 hours of normal time and is doing one-eighth of the remaining 102 hours for an eight-man rota he will be personally responsible for patients' care for about 72 hours per week. This is what the Secretary of State is requiring of Dr Buckley at a time when the national standard working week is 38 hours and when the Government impose restrictions on the working hours of coach and lorry drivers and airline pilots.
However, while absolutely condemning the Secretary of State and the Walsall FPC, it would seem appropriate to remember the part which medical practitioners have played in this matter. Since the Southampton Annual Representative Meeting of the BMA in 1972 I have, through the appropriate constituencies, tabled a series of resolutions relating to the ability of practitioners to use deputising services, and these have been rejected by the ARM on at least two occasions and have not been discussed on other occasions. When they have not been discussed I have invariably provided a memorandum so that they could be considered by the Council of the Association, and the General Medical Services Committee has considered the matter on each of these occasions and has been unable to support any of the proposals.

The profession must accept much of the blame for the situation in which Dr Buckley now finds himself.

DERMOT LYNCH

Hanworth

Feltham, Middx

\section{Work of community physicians}

SIR,-The Central Committee for Community Medicine recently set up a working party to review the work undertaken by community physicians since the reorganisation of the NHS and how it relates to the theoretical assumptions made prior to reorganisation.

The committee is anxious to assemble as much information as possible and invites anyone who has comments or opinions to send them to the secretary of the Working Party on the State of Community Medicine.

G D DUNCAN Chairman,
Party as the Working Party as the
State of Community Medicine

BMA House,

\section{Changing the FRCS exam}

SIR,-Mr P F Jones (25 October, p 1145) is, of course, referring only to discussions which have occurred in the Royal College of Surgeons of Edinburgh concerning possible changes in their own FRCS examinations.

During the seven years I have served on Council of the Royal College of Surgeons of England I am happy to report that the primary and final FRCS examinations have been kept under regular review. Changes of a minor character have been made in the primary FRCS examination but there has been no disposition to effect radical changes in the character and/or timing of either our primary or final examinations.

My personal views happen to coincide with those of Professor Roy Calne (8 October, p 952 and in the Annals of the Royal College of Surgeons of England (November 1977, p 514)). However, it would be for the Council of the Royal College of Surgeons of England to decide if any alteration should be made in our own examinations and, for the general reassurance of all our Fellows as well as those in training, may I clearly state that we are not at present planning any changes.

Reginald MURLeY

London, wC2
REGINALD MURLEY
President,
Royal College of Surgeons of England 